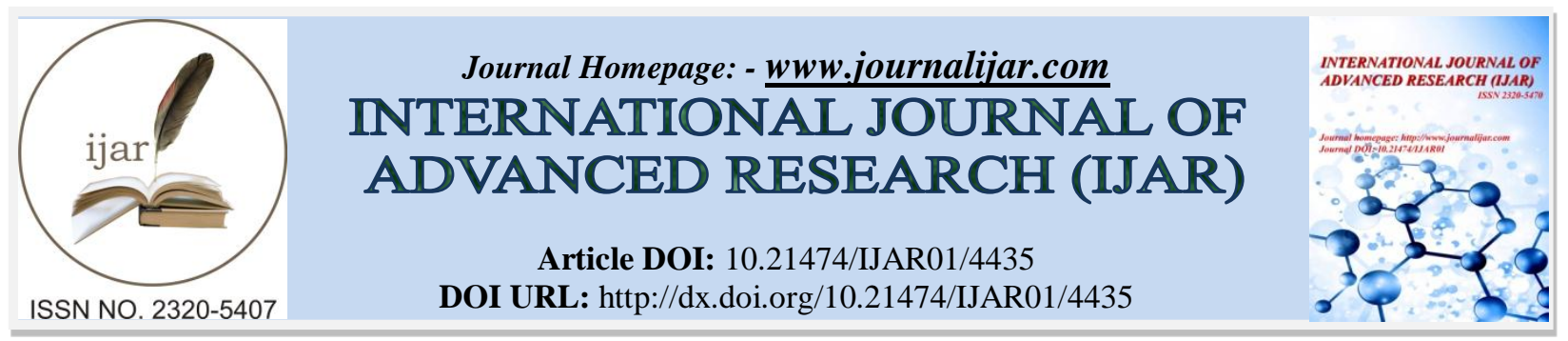

RESEARCH ARTICLE

\title{
EFFECT OF DURATION OF MENOPAUSE ON SERUM LIPID PROFILE IN POSTMENOPAUSAL
} WOMEN

*Sivapriya. A and Santhanalakshmi. L.

Madurai Medical College, Madurai, Tamilnadu.

\section{Manuscript Info}

Manuscript History

Received: 10 April 2017

Final Accepted: 12 May 2017

Published: June 2017

Key words:-

Cardiovascular disease, Lipid profile,

Postmenopausal

\section{Abstract}

Background: Female coronary heart disease morbidity rate accelerate after the age of 45years. Altered serum lipid profile seen in menopause is one of the major determinants for developing cardiovascular diseases. Changes in lipid level in relation to the duration of menopause is to be investigated to prevent the emerging cardiovascular diseases.

Aim and objective: To study the effect of duration of menopause on serum lipid profile in postmenopausal women.

Methods: After getting ethical committee approval, in this cross sectional study, postmenopausal women attending Government Rajaji Hospital for master health checkup were selected. Women with duration of menopause less than 10years $(n=30)$ were taken as group-I and more than 10years $(n=30)$ were taken as group-II and estimation of serum lipid profile was done for all of them.

Results: Statistical analysis was done by student's t test and the results were compared between group-I and group-II. In group-II, the mean values of total cholesterol $(\mathrm{p}=0.006)$ and low density lipoprotein levels $(\mathrm{p}<0.001)$ were increased significantly. However there was a significant decrease in high density lipoprotein level $(\mathrm{p}<0.001)$.

Conclusion: The elevated low density lipoprotein and the reduction of high density lipoprotein level increases the risk of developing cardiovascular diseases. So specific health education strategies are needed in postmenopausal women of longer duration.

Copy Right, IJAR, 2017,. All rights reserved.

\section{Introduction:-}

Menopause is a normal physiological change wherein the permanent stoppage of menstruation takes place. Primarily menopause is due to loss of stocks of oocyte in the ovary with a consequent fall in the level of hormones like oestrogen and progesterone. Lipid metabolism is affected by the level of oestrogen. Altered serum lipid profile is associated with menopause and thus it is a major determining factor predisposing to cardiovascular diseases.

According to Framingham study, morbidity due to coronary heart disease accelerate more quickly in females of age more than 45years than those of males. It makes the screening of postmenopausal women for abnormal lipid profile mandatory. Significance of duration of menopause on serum lipid profile is to be investigated so that postmenopausal women can undergo further evaluation and earlier management. 


\section{Aim:-}

To compare the lipid levels between the two groups of postmenopausal women who are divided based on the duration of menopause and to find out the effect of duration of menopause on serum lipid profile.

\section{Study Design:-}

Cross sectional study.

\section{Study group:-}

Body mass index matched 60 postmenopausal women are divided into two groups. GROUP I consists of 30 postmenopausal women with duration of menopause less than 10years and GROUP II consists of 30 postmenopausal women with duration of menopause more than 10years.

\section{Inclusion Criteria:-}

1. Age between 45 - 60 years

2. Attained natural menopause

3. Not on hormone replacement therapy

\section{Exclusion Criteria:-}

1. Known congenital and acquired heart diseases

2. Systemic diseases - Hypertension, Diabetes mellitus, Hepatic and Metabolic diseases

3. Chronic drug intake like Rifampicin, Phenytoin, Anticoagulants, Statins etc

4. Thyroid dysfunction

5. Smoking

\section{Materials and Methodology:-}

After getting approval from the ethical committee, healthy postmenopausal women attending Government Rajaji Hospital for master health checkup were selected. Informed and written consent were obtained from them. Detailed medical history, general and systemic examination were carried out. Routine biochemical investigations were done. 60 eligible candidates for the study were selected and were divided into two groups with 30 in each group depending upon the duration of menopause. After 10-12 hours of fasting, under sterile precautions $3 \mathrm{ml}$ of venous blood sample was collected and lipid profile estimation was done by enzymatic method.

\section{Results and Analysis:-}

Statistical analysis of lipid profile values was done by student's $\mathbf{t}$ test and the results were compared between group-I and group-II. The statistical significance was drawn at 'p'- value of $<\mathbf{0 . 0 1}$. By means of SPSS software version 16, analysis of statistics was performed.

\begin{tabular}{|c|c|c|c|c|c|}
\hline \multirow[t]{2}{*}{ Parameters } & \multicolumn{2}{|c|}{ Group I $(\mathbf{N}=\mathbf{3 0})$} & \multicolumn{2}{|c|}{ Group II $\quad(\mathrm{N}=\mathbf{3 0})$} & \multirow[t]{2}{*}{ 'p' value } \\
\hline & Mean & SD & Mean & SD & \\
\hline $\begin{array}{l}\text { Total cholesterol } \\
(\mathrm{mg} / \mathrm{dl})\end{array}$ & 164.88 & 24.289 & 184.05 & 22.010 & $\begin{array}{l}\text { 0.006 } \\
\text { (significant) }\end{array}$ \\
\hline $\begin{array}{l}\text { High density } \\
\text { lipoprotein } \\
\text { (mg/dl) }\end{array}$ & 44.53 & 7.860 & 32.77 & 4.606 & $\begin{array}{l}\text { 0.000 } \\
\text { (significant) }\end{array}$ \\
\hline $\begin{array}{l}\text { Low density } \\
\text { lipoprotein (mg/dl) }\end{array}$ & 94.72 & 22.437 & 127.71 & 23.430 & $\begin{array}{l}\text { 0.000 } \\
\text { (significant) }\end{array}$ \\
\hline $\begin{array}{l}\text { Very low density } \\
\text { lipoprotein (mg/dl) }\end{array}$ & 24.85 & 5.421 & 25.95 & 6.635 & 0.365 \\
\hline Triglycerides (mg/dl) & 123.47 & 28.084 & 129.95 & 32.083 & 0.714 \\
\hline
\end{tabular}

While comparing the mean values of lipid profile between the two groups, total cholesterol and low density lipoprotein levels are increased significantly. Level of very low density lipoprotein and triglycerides are increased but it is insignificant. There is a significant decrease in high density lipoprotein level. 


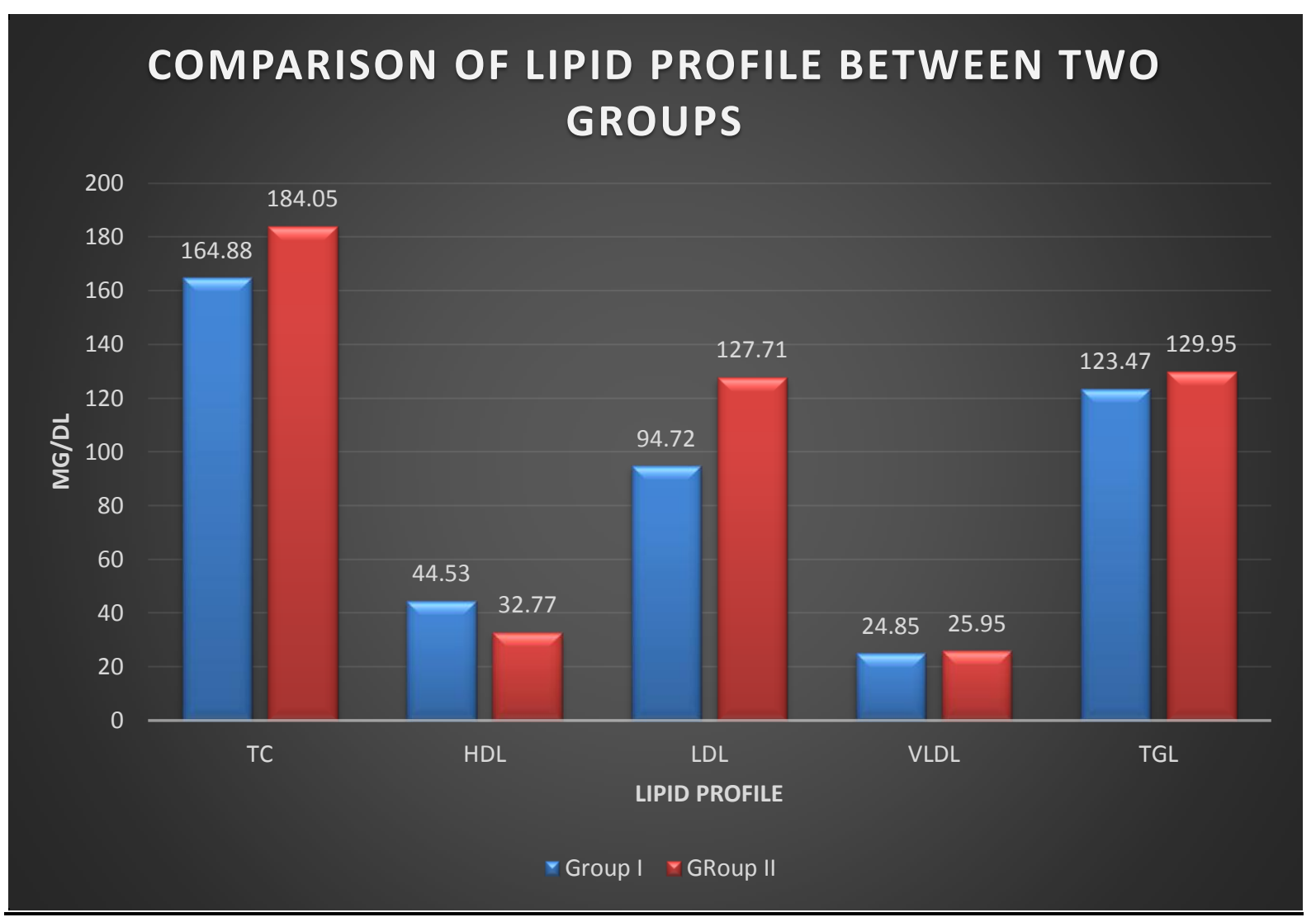

\section{Mechanism:-}

Derangement in lipid profile after menopause is primarily due to oestrogen deficiency. Oestrogen increases the level of high density lipoprotein by decreasing the hepatic lipase activity which catabolizes the high density lipoprotein. Oestrogen decreases the oxidation of low density lipoprotein and increases the hepatic expression of low density lipoprotein receptors thereby decreasing the level of low density lipoprotein by accelerating the clearance.

After menopause due to loss of oestrogen changes that occur in the lipid profile are not friendly for the cardiovascular health of women. Oxidation of low density lipoprotein results in the formation of foam cells which lead to atherosclerosis. As the duration of menopause increases, adverse changes in lipid level occur due to long term effect of oestrogen deficiency.

\section{Discussion:-}

According to Health and Family Welfare Ministry of India the life expectancy for females is increased from 63.9 years in 2001-2005 to 69.6 years in 2011-2015 and with the rise in life expectation in females, number of postmenopausal women is increasing. A woman today has to live for about one third of her life beyond menopause. American Heart Association report (2002) states that $70 \%$ of women develop cardiovascular disease after menopause.

In our present study, we have divided the postmenopausal women into two groups based on the duration of menopause. The mean age of postmenopausal women in group I is $46.73 \pm 2.23$ years and group II is $57.53 \pm 2.03$ years. The mean duration of menopause in group I is $3.2 \pm 0.71$ years and group II is $12.6 \pm 1.35$ years. Serum lipid levels vary in every individuals and they depend on body mass index, level of exercise, history of smoking, dietary habits, systemic diseases like hypertension, diabetes mellitus, liver and metabolic diseases (Gordon T et al., 1981). So in our study, we excluded these confounding variables.

In our study, in group II, the mean values of total cholesterol $(\mathrm{p}=0.006)$ and low density lipoprotein level $(\mathrm{p}<0.001)$ were increased significantly. However there was a significant decrease in high density lipoprotein level $(\mathrm{p}<0.001)$. 
As the duration of menopause increases, more derangement is seen in the lipid profile values. The elevated low density lipoprotein level and the reduction in high density lipoprotein level increases the risk of developing cardiovascular diseases.

\section{Conclusion:-}

Regular monitoring of lipid profile is mandatory in postmenopausal women by which secondary prevention of cardiovascular diseases is possible. Specific health strategies like dietary interventions, increased physical activity and lipid lowering drugs are proved to be useful. Postmenopausal oestrogen replacement apparently protects against cardiovascular disease in women partly through its beneficial effects on lipid levels.

\section{Referances:-}

1. Gordon T, Kanne E.B, Castelli W.P, Dawber T.R. Lipoprotein cardiovascular disease and death. The Framingham study; Arch.Intern Med, 1981; 141: 1128

2. Kalavathi L, H R Dhruvnarayan and Elizabeth Zachariah. Plasma estradiol and lipid profile in perimenopausal women. Indian J Physiol 1991;35(4):260-262.

3. P Pradhan, AV Upadhya. A study of coronary heart disease in postmenopausal women and identification of major modifiable determinant risks for its prevention 10.5005/JP - journals - 10032-1013.

4. Dr. M. Swarna Latha MD., DGO., and Dr. R. Geeta Vandana MD., A Comparative Study of Serum Lipid Profile between Pre and Postmenopausal Women. e-ISSN: 2279-0853, p-ISSN: 2279-0861.Volume 14, Issue 4 Ver. VIII (Apr. 2015), PP 51-53.

5. Swarnalatha P K and Ebrahim NKCA correlative study of estrogen and lipid profile in premenopausal and postmenopausal women. IJBAR (2012) 03(11). 